4) $\mathrm{PbO}, \mathrm{Nb}_{2} \mathrm{O}_{5}, \mathrm{TiO}_{2}$ 等を含有する高屈折高分散 ガラスにおいて， $n_{\mathrm{D}}$ が 1.95 より大きい場合， $\nu_{\mathrm{D}}$ が 22 より小さい場合，または $\lambda_{0}$ が $170 \mathrm{~nm}$ より長波長 にある場合には，ガラスの吸収端 $\lambda_{\mathrm{abs}=1}$ は $370 \mathrm{~nm}$ よ り大きく，このようなガラスでは無色のガラスを得るこ とがほとんど不可能に近い。

\section{文献}

1）金 炳勲, 山根正之, 窵協, 88, 191 (1980).
2）金 炳勲, 山根正之, 窝協, 89, 216 (1981).

3）金 炳勲，山根正之，窯協，89，323-29 (1981)。

4）金 炳等, 山根正之, 墨協, 89, 564-67 (1981).

5) M. Didomenico, Jr. and S.H. Wemple, J. Appl. Phys., 40, 720 (1969).

6) G.H. Sigel, Jr., J. Phys. Chem. Solids, 32, 2373 (1971).

7) A.J. Bourdillon, F. Khumalo and J. Bordas, Phil. Mag., B 37, 731 (1978).

論 文・Paper

\title{
Formation Process and Optical Absorption Edge of Amorphous $\mathrm{As}_{2} \mathrm{~S}_{3}$ Films
}

\author{
Noboru TOHGE, Masahiko KIMOTO, Tsutomu MINAMI and \\ Masami TANAKA \\ $\left(\begin{array}{l}\text { Department of Applied Chemistry, College of Engineering, University of Osaka Prefecture } \\ \text { 4-804, Mozu-Umemachi, Sakai-shi } 591\end{array}\right)$
}

\begin{abstract}
For amorphous $\mathrm{As}_{2} \mathrm{~S}_{3}$ films deposited at temperatures from $-170^{\circ} \mathrm{C}$ to $170^{\circ} \mathrm{C}$, optical absorption edges, IR spectra, and thermally induced changes of these optical properties were studied as a function of the deposition temperature. As-deposited films contained $\mathrm{As}_{4} \mathrm{~S}_{4}$ and sulfur components, the amount of which was highly dependent on the deposition temperature; as the deposition temperature decreased, the amount of these components increased. From these observations, the decomposition of $\mathrm{As}_{2} \mathrm{~S}_{3}$ glass to $\mathrm{As}_{4} \mathrm{~S}_{4}$ and sulfur components in the evaporation process was proposed. Annealing of as-deposited films at temperatures near glass transition caused the reaction of residual $\mathrm{As}_{4} \mathrm{~S}_{4}$ and sulfur components, accompanying the shift of absorption edge to lower photon energies. From the compositional analysis, it was found that the films deposited at temperatures higher than $100^{\circ} \mathrm{C}$ was sulfur-poor compared with the stoichiometric composition. The dependence of optical band gap on the deposition temperature for annealed films was explained in terms of the remaining $\mathrm{As}_{4} \mathrm{~S}_{4}$ component and/or sulfur deficiency in the films.

[Received May 18, 1981]
\end{abstract}

\section{$\mathbf{A s}_{2} \mathbf{S}_{3}$ 非晶質薄膜の生成過程と光学吸収端}

峠

\author{
登・木本匡彦・南努・田中雅美 \\ (大阪府立大学 工学部 応用化学科)
}

$\mathrm{As}_{2} \mathrm{~S}_{3}$ 非晶質薄膜の光学吸収端, IR スペクトル, 及びこれら光学的性質の熱処理による変化と, 薄膜の析出温度との関係を, $-170^{\circ} \sim 170^{\circ} \mathrm{C}$ の温度範囲で調べた。蒸着したままの薄膜中には, $\mathrm{As}_{4} \mathrm{~S}_{4}$ と硫黄成分が残存しており，それらの量は析出温度が低くなるに従って増加した。このこと から, $\mathrm{As}_{2} \mathrm{~S}_{3}$ ガラスは蒸着の際には $\mathrm{As}_{4} \mathrm{~S}_{4}$ と硫黄成分に分解すると推察した。薄膜をガラス転移 温度付近の温度で熱処理すると, 残存していた $\mathrm{As}_{4} \mathrm{~S}_{4}$ と硫黄成分が反応し, $\mathrm{As}_{2} \mathrm{~S}_{3}$ バルクガラス に非常によく似た構造に変化した．これが，熱処理による光学吸収端の低光子エネルギー方向への 移動の原因であると考えられる. 得られた薄膜の組成分析の結果, 析出温度が $100^{\circ} \mathrm{C}$ 以上の薄膜で は, 硫黄成分が化学量論組成よりも不足していることが見いだされた。したがって, 熱処理薄膜に 
おりる光学的バンドギャップの析出温度依存性は, $\mathrm{As}_{4} \mathrm{~S}_{4}$ 成分の残存とイオウ成分の不足, あるい はそのいずれかに起因しているものと考えられる。

\begin{abstract}
Key-words : Amorphous chalcogenide films, Chalcogenide glasses, IR spectra, Absorption edge shift
\end{abstract}

\section{Introduction}

Amorphous chalcogenides of group $4 \mathrm{~B}$ and $5 \mathrm{~B}$ elements have been attracting much attention in this decade as an image-storage medium, as well as semiconductors, ever since the efficient storage of a hologram on amorphous $\mathrm{As}_{2} \mathrm{~S}_{3}$ films was reported ${ }^{11}$. Several of chemical and physical properties of these materials vary with light illumination and annealing $^{2) ~ 6)}$. These phenomena are applicable to image storage, photoresist, and so on.

The optical absorption edge of chalcogenide films is one of properties exhibiting remarkable changes by annealing and light illumination ${ }^{47}, 7$. Annealing of as deposited films shifts the absorption edge irreversibly to lower photon energies and subsequent light illumination causes further shift of the edge to the same direction. The latter change is referred to as "photo-darkening" and reversibly recovered by annealing. The mechanism of these thermally and optically induced changes, however, has not been completely explained.

In a previous note on IR spectra of amorphous $\mathrm{As}_{2} \mathrm{~S}_{3}$ films deposited at different temperatures, we reported that the structure of as-deposited films was highly dependent on the deposition temperature ${ }^{8)}$. There are some papers on thermally induced change in structure of evaporated $\mathrm{As}_{2} \mathrm{~S}_{3}$ films ${ }^{9}$. However, the relation between optical properties and structures has not been systematically studied. The present paper describes optical absorption edge of these films and its thermally induced change as a function of the deposition temperature. Based on the structural information from the IR spectra, a formation process of amorphous $\mathrm{As}_{2} \mathrm{~S}_{3}$ films and a mechanism of thermally induced change in the absorption edge are discussed.

\section{Experimental}

The films were evaporated at a rate of 1.5 $\sim 2 \mu \mathrm{m} / \mathrm{min}$ in a vacuum of $\sim 2 \times 10^{-6}$ Torr on cover-glasses or silicon wafers for the measurements of optical transmission or IR spectra, respectively. Precautions were taken to heat the quartz-glass crucible containing pulverized $\mathrm{As}_{2} \mathrm{~S}_{3}$ glasses at nearly the constant temperature $\left(400^{\circ} \sim 500^{\circ} \mathrm{C}\right)$ for each run. The deposition temperature of the films was varied in the range of $-170^{\circ} \mathrm{C}$ to $170^{\circ} \mathrm{C}$ by controlling the substrate temperature to an accuracy of $\pm 5^{\circ} \mathrm{C}$.

The optical transmission of the films was measured at room temperature using the system reported previously ${ }^{10)}$; transmission of even $\sim 10^{-4} \%$ could be detected. Optical absorption coefficients were evaluated from the transmission data, taking account of film thickness and reflectance at the surfaces. IR spectra were measured using an IR spectrophotometer (JASCO, DC-700 G). Annealing was carried out in a dry nitrogen stream at $200^{\circ} \mathrm{C}$ for $1 \mathrm{~h}$. The composition of the films obtained was analyzed using an X-ray microanalyzer (JEOL, JSM-50 A).

\section{Results}

\subsection{Optical absorption edge of} evaporated $\mathrm{As}_{2} \mathrm{~S}_{3}$ films

\subsubsection{Thermally and optically induced changes in absorption edge}

Figure 1 is an example of the dependence of absorption coefficient $\alpha$ on photon energy $h \nu$ in the vicinity of optical absorption edge for the film at various stages : as-deposited at $5^{\circ} \mathrm{C}$ (a), annealed at $200^{\circ} \mathrm{C}$ for $1 \mathrm{~h}$ (b), and illuminated at $-160^{\circ} \mathrm{C}$ (c). Annealing at $200^{\circ} \mathrm{C}$, which is close to the glass transition temperature reported for $\mathrm{As}_{2} \mathrm{~S}_{3}$ bulk glass ${ }^{11), 12)}$, shifts irreversibly the absorption edge to lower energies $((a) \rightarrow(b))$ and subsequent illumination at $-160^{\circ} \mathrm{C}$ of light from xenon lamp $(300 \mathrm{~W})$ causes further shift of the edge to lower energies $((\mathrm{b}) \rightarrow(\mathrm{c}))$. The latter change caused by illumination can be recovered by annealing at $200^{\circ} \mathrm{C}((\mathrm{c}) \rightarrow(\mathrm{b}))$. The present paper is mainly concerned with the irreversible change by heat-treatment $((a) \rightarrow(b))$. Here the photon energy extrapolated to zero of $\sqrt{\alpha h \nu}$ vs. $h \nu$ plots is adopted as the optical band 
gap $E_{\mathrm{g}}{ }^{\text {opt }}$, as shown in the figure by a dashed line.

\subsubsection{Dependence of optical band gap on deposition temperature}

The optical band gap $E_{\mathrm{g}}{ }^{\mathrm{opt}}$ is plotted against the deposition temperature $T_{\mathrm{d}}$ in Fig. 2 for as-deposited (open circles) and annealed films (closed circles). The optical band gap of films deposited at temperatures lower than $5^{\circ} \mathrm{C}$ is almost constant $(\sim 2.33 \mathrm{eV})$. With further

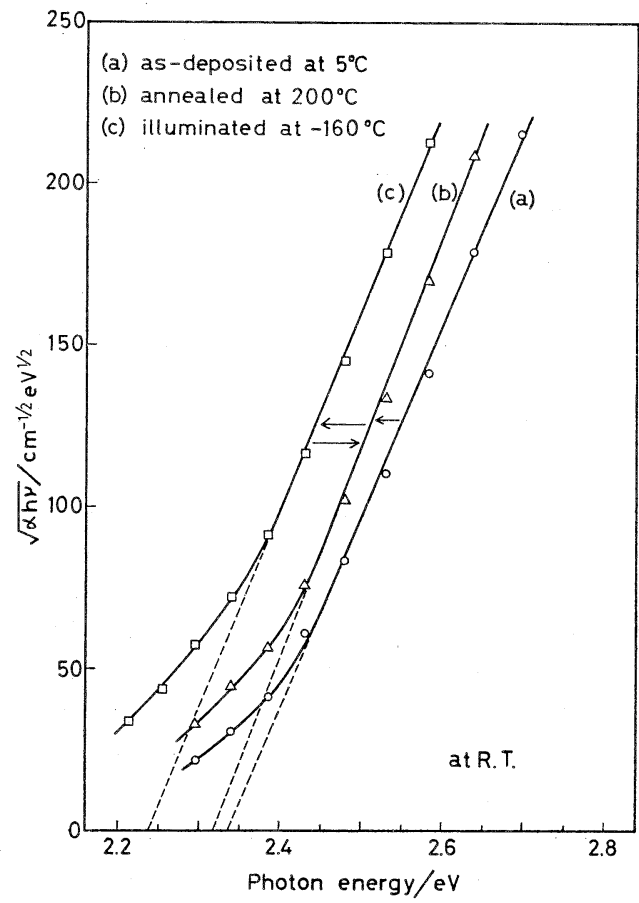

Fig. 1. Optical absorption coefficient vs. photon energy in the vicinity of absorption edge and its changes by annealing and light illumination for the amorphous $\mathrm{As}_{2} \mathrm{~S}_{3}$ film deposited at $5^{\circ} \mathrm{C}$.

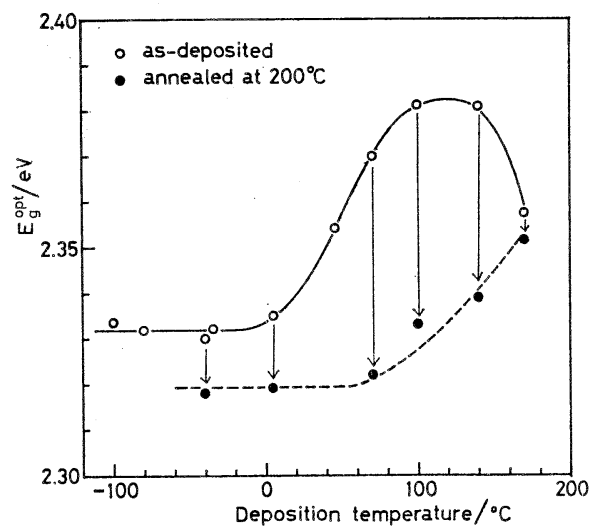

Fig. 2. Optical band gap of as-deposited (open circles) and annealed films (closed circles) as a function of deposition temperature. increase in $T_{\mathrm{d}}, E_{\mathrm{g}}{ }^{\mathrm{opt}}$ increases, passes a maximum $(\sim 2.38 \mathrm{eV})$ at around $T_{\mathrm{d}}=120^{\circ} \mathrm{C}$, and then decreases. On the other hand, annealing at temperatures near glass transition reduces $E_{\mathrm{g}}{ }^{\mathrm{opt}}$ for all the films. The optical band gap of annealed films remains constant $(\sim 2.32 \mathrm{eV})$ for $T_{\mathrm{d}}<80^{\circ} \mathrm{C}$ and then monotonously increases with increase in $T_{\mathrm{d}}$. It is noticeable that $E_{\mathrm{g}}{ }^{\text {opt }}$ of the film deposited at $170^{\circ} \mathrm{C}$ is little reduced by annealing.

\subsection{IR spectra of evaporated $\mathrm{As}_{2} \mathrm{~S}_{3}$ films}

\subsubsection{IR spectra of as-deposited films}

Figure 3 shows IR spectra in the range of $450 \mathrm{~cm}^{-1}$ to $200 \mathrm{~cm}^{-1}$ for the films as-deposited at different $T_{\mathrm{d}}$. There are two strong absorptions at $375 \mathrm{~cm}^{-1}$ and $340 \mathrm{~cm}^{-1}$ and a shoulder at $310 \mathrm{~cm}^{-1}$ for the film deposited at $-170^{\circ} \mathrm{C}$. With increase in $T_{\mathrm{d}}$, the latter shoulder grows to a strong absorption which is observable in $\mathrm{As}_{2} \mathrm{~S}_{3}$ bulk glass ${ }^{13)}$. As previously reported ${ }^{8}$, the two absorptions at $375 \mathrm{~cm}^{-1}$ and $340 \mathrm{~cm}^{-1}$ agree in wavenumber with the absorptions characteristic of crystalline $\beta-\mathrm{As}_{4} \mathrm{~S}_{4}: 375 \mathrm{~cm}^{-1}$ and $345 \mathrm{~cm}^{\left.-1{ }^{14}\right)}$. On the other hand, the absorption at $310 \mathrm{~cm}^{-1}$ is assigned to the antisymmetric As-S streching mode of $\mathrm{AsS}_{3}$ pyramidal structural units in $\mathrm{As}_{2} \mathrm{~S}_{3}$ bulk glass ${ }^{13)}$. The results therefore suggest the presence of

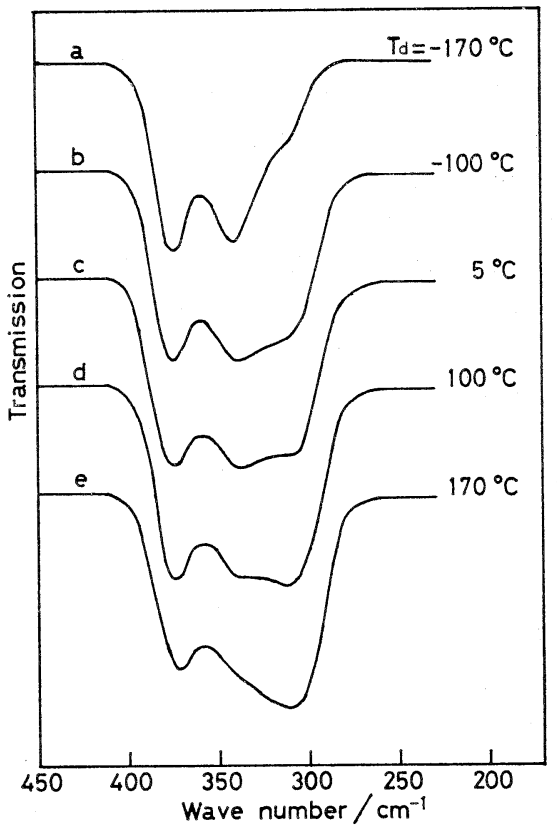

Fig. 3. IR spectra of $\mathrm{As}_{2} \mathrm{~S}_{3}$ films as-deposited at different temperatures. 


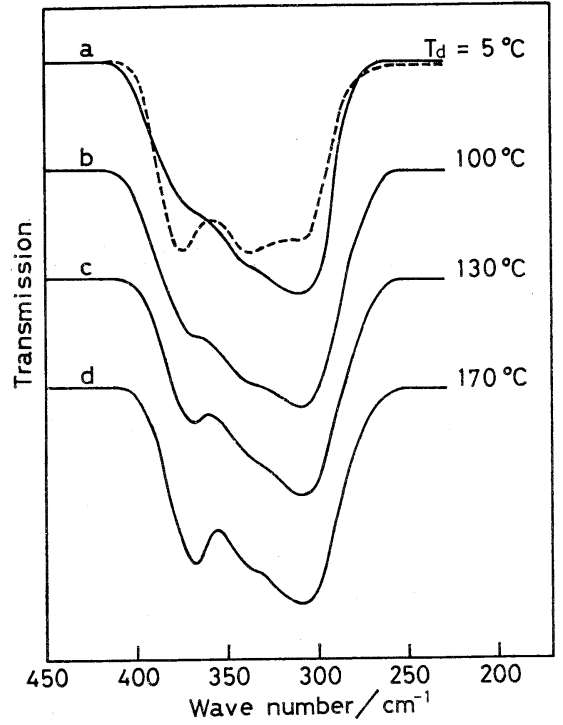

Fig. 4. IR spectra of $\mathrm{As}_{2} \mathrm{~S}_{3}$ films deposited at temperatures shown in the figure and subsequently annealed at $200^{\circ} \mathrm{C}$ for $1 \mathrm{~h}$. The spectrum represented by a broken line is shown for comparison with the as-deposited film; the spectrum is cited from Fig. $3\left(T_{\mathrm{d}}=5^{\circ} \mathrm{C}\right)$ as an example.

$\mathrm{As}_{4} \mathrm{~S}_{4}$ component in as-deposited films, the amount of which decreases with increase in $T_{\mathrm{d}}$.

\subsubsection{IR spectra of annealed films}

IR spectra of annealed $\mathrm{As}_{2} \mathrm{~S}_{3}$ films with different $T_{\mathrm{d}}$ are shown in Fig. 4. Comparison of the spectra with those in Fig. 3 indicates that annealing intensifies the absorptions at $310 \mathrm{~cm}^{-1}$, whereas it weakens the absorptions at $375 \mathrm{~cm}^{-1}$ and $340 \mathrm{~cm}^{-1}$. Especially, for the films with rather low $T_{\mathrm{d}}\left(<100^{\circ} \mathrm{C}\right)$, the absorptions originated from $\mathrm{As}_{4} \mathrm{~S}_{4}$ component have disappeared and the absorption at $310 \mathrm{~cm}^{-1}$ dominates; the resultant spectra are very similar to that of $\mathrm{As}_{2} \mathrm{~S}_{3}$ bulk glass. However, it should be noticed that for the films with higher $T_{\mathrm{d}}$ than $100^{\circ} \mathrm{C}$, the change in IR spectra is slight and the absorption at $375 \mathrm{~cm}^{-1}$ is still appreciable.

\section{Discussion}

\subsection{Formation process of amorphous $\mathbf{A s}_{2} \mathbf{S}_{3}$ films}

Evaporated films are formed via several steps; (1) evaporation of gaseous species, (2) deposition of the gaseous species on a substrate, and (3) reaction of the deposited species on the substrate to form a film. The substrate temperature or deposition temperature is a principal factor to govern the processes (2) and (3). In particular, when the substrate is kept at low temperatures, the reaction of deposited species (process (3)) is suppressed, and hence it is expected that deposited species remain in the films.

The result in Fig. 3 shows that as-deposited films contain an increasing amount of $\mathrm{As}_{4} \mathrm{~S}_{4}$ component with decrease in $T_{\mathrm{d}}$. This observation reveals the following decomposition occurs in the evaporation of $\mathrm{As}_{2} \mathrm{~S}_{3}$ glass,

$$
2 \mathrm{As}_{2} \mathrm{~S}_{3} \rightarrow \mathrm{As}_{4} \mathrm{~S}_{4}+\mathrm{S}_{2} \text {. }
$$

Sulfur component in as-deposited films was not confirmed directly from IR spectra. Its presence, however, is reasonably supposed from the facts that IR spectra of the films deposited at low temperatures changed to those of stoichiometric $\mathrm{As}_{2} \mathrm{~S}_{3}$ glass after annealing and that the atomic ratio of $A s$ to $S$ in the films was nearly $2 / 3$ except for the films deposited at rather high temperatures, as described in 4.2. Deposited $\mathrm{As}_{4} \mathrm{~S}_{4}$ and sulfur components on a substrate react to form $\mathrm{As}_{2} \mathrm{~S}_{3}$ amorphous films, the degree of the reaction being of great dependence on the deposition temperature : decrease in the deposition temperature depresses the reaction of $\mathrm{As}_{4} \mathrm{~S}_{4}$ with sulfur components.

\subsection{Annealing effect on the structure of $\mathrm{As}_{2} \mathrm{~S}_{3}$ films}

Annealing of the evaporated films weakens the IR absorptions at $375 \mathrm{~cm}^{-1}$ and $340 \mathrm{~cm}^{-1}$ due to the $\mathrm{As}_{4} \mathrm{~S}_{4}$ component. This indicates that annealing facilitates the reaction of residual $\mathrm{As}_{4} \mathrm{~S}_{4}$ and sulfur components and thereby causes a structural transformation in the films to the structure very similar to that of $\mathrm{As}_{2} \mathrm{~S}_{3}$ bulk glass. As already pointed out, for the films deposited at temperatures higher than $100^{\circ} \mathrm{C}$, the absorptions originated from the $\mathrm{As}_{4} \mathrm{~S}_{4}$ component are appreciable even after the sufficient annealing. This observation is associated with deviation in composition of these films from stoichiometry. In Fig. 5, the As $\mathrm{K}_{\alpha}$ / $\mathrm{S} \mathrm{K}_{\alpha}$ ratio for the four films with different $T_{\mathrm{d}}$ is plotted on the calibration line which was determined for $\mathrm{As}_{4} \mathrm{~S}_{4}$ crystal and bulk glasses $\mathrm{As}_{2} \mathrm{~S}_{3}$ and $\mathrm{As}_{3} \mathrm{~S}_{7}$. Sulfur is obviously poor for the films deposited at higher $T_{\mathrm{d}}$ than $100^{\circ} \mathrm{C}$. It is therefore concluded that the $\mathrm{As}_{4} \mathrm{~S}_{4}$ component remains unreacted in annealed films with high $T_{\mathrm{d}}$ due to sulfur deficiency from 


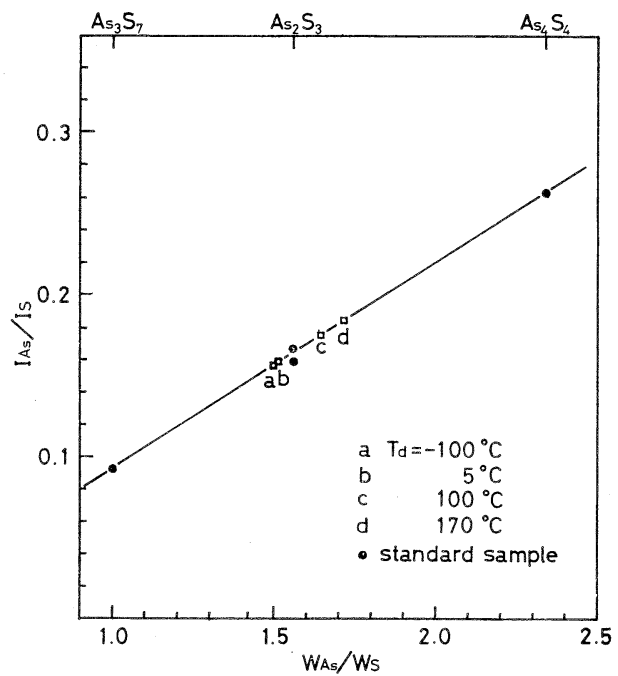

Fig. 5. Plot of the $\mathrm{As} \mathrm{K}_{\alpha} / \mathrm{S} \mathrm{K}_{\alpha}$ ratio against the weight ratio of $A s$ to $S$. The calibration line was determined for $\mathrm{As}_{4} \mathrm{~S}_{4}$ crystal and bulk glasses $\mathrm{As}_{2} \mathrm{~S}_{3}$ and $\mathrm{As}_{3} \mathrm{~S}_{7}$

\section{stoichiometry.}

\subsection{Optical band gap of as-deposited films and its thermally induced change}

As discussed above, as-deposited $\mathrm{As}_{2} \mathrm{~S}_{3}$ films contain residual $\mathrm{As}_{4} \mathrm{~S}_{4}$ and sulfur components. Accordingly, the measured $E_{\mathrm{g}}{ }^{\text {opt }}$ of as-deposited films is the apparent optical band gap related to these components. Details of the contribution of these components to the optical band gap are not clear at present stage, but would be complex because the dependence of $E_{\mathrm{g}}{ }^{\text {opt }}$ on $T_{\mathrm{d}}$ is not monotonous. The decrease in $E_{\mathrm{g}}{ }^{\text {opt }}$ for as-deposited films with higher $T_{\mathrm{d}}$ than $120^{\circ} \mathrm{C}$ can be explained by considering that these films were exposed to annealing to some extent during deposition.

The dependence of $E_{\mathrm{g}}{ }^{\mathrm{opt}}$ on $T_{\mathrm{d}}$ for annealed films can be understood in terms of the variation in composition of the films; the increase in $E_{\mathrm{g}}{ }^{\text {opt }}$ for the films with higher $T_{\mathrm{d}}$ than $100^{\circ} \mathrm{C}$ is possibly ascribed to the remaining $\mathrm{As}_{4} \mathrm{~S}_{4}$ component and/or sulfur deficiency, as revealed in IR spectra and compositional analysis.

\section{Conclusions}

For amorphous $\mathrm{As}_{2} \mathrm{~S}_{3}$ films deposited on temperature-controlled substrates, optical absorption edges, IR spectra, and thermally induced changes of these optical properties were studied as a function of the deposition temperature. The formation process of the films was discussed on the basis of the experimental results. The following conclusions were obtained :

(1) As-deposited films contain $\mathrm{As}_{4} \mathrm{~S}_{4}$ and sulfur components, the amount of which is highly dependent on the deposition temperature; as the deposition temperature decreases, the amount of these components increases. From these observations, the decomposition of $\mathrm{As}_{2} \mathrm{~S}_{3}$ glass to $\mathrm{As}_{4} \mathrm{~S}_{4}$ and sulfur components in the evaporation process was proposed.

(2) Annealing at temperatures near glass transition causes the reaction of residual $\mathrm{As}_{4} \mathrm{~S}_{4}$ and sulfur components in as-deposited films, accompanying the shift of absorption edge to lower photon energies.

(3) Compositional analysis proved that the films deposited at temperatures higher than $100^{\circ} \mathrm{C}$ was sulfur-poor compared with the stoichiometric composition. The dependence of optical band gap on the deposition temperature for annealed films was explained in terms of the remaining $\mathrm{As}_{4} \mathrm{~S}_{4}$ component and/or sulfur deficiency in the films.

Acknowledgement The authors wish to thank the personnel of Osaka Radiation Center for kind permission to use an IR spectrophotometer (JASCO, DC-700 G).

This work was partly supported by a Grant-in-Aid for Scientific Research from the Ministry of Education, Science, and Culture.

\section{References}

1) S.A. Keneman, Appl. Phys. Lett., 19, 205 (1971).

2) J.S. Berkes, S.W. Ing, Jr. and W.J. Hillegas, J. Appl. Phys., 42, 4908 (1971).

3) T. Igo and Y. Toyoshima, J. Non-Crystalline Solids, 11, 304 (1973).

4) J.P. de Neufville, S.C. Moss and S.R. Ovshinsky, J. Non-Crystalline Solids, 13, 191 (1973/74).

5) H. Nagai, A. Yoshikawa, Y. Toyoshima, O. Ochi and Y. Mizushima, Appl. Phys. Lett., 28, 145 (1976).

6), B.T. Kolomiets and V.M. Lyubin, Mater. Res. Bull., 13, 1343 (1978).

7) K. Tanaka, Solid State Commun., 15, 1521 (1974) ; Appl. Phys. Lett., 25, 243 (1975).

8) N. Tohge, M. Kimoto, T. Minami and M. Tanaka, Jpn. J. Appl. Phys., 19, 213 (1980).

9) For example, Ref. 4); S.A. Solin and G.N. Papatheodorou, Phys. Rev. B, 15, 2084 (1977).

10) N. Tohge, T. Hirose, T. Minami and M. Tanaka, Yogyo-Kyokai-Shi 89, 451 (1981).

11) S.S. Flaschen, A.D. Pearson and W.R. Northover, J. Am. Ceram. Soc., 43, 274 (1960).

12) M. Tanaka, T. Minami and M. Hattori, Jpn. J. 
Appl. Phys., 5, 185 (1966).

13) G. Lucouvsky and R.M. Martin, J. Non-Crystalline Solids 8-10, 185 (1972).
14) A. Bertoluzza, C. Fagnano, P. Monti and G. Semerano, J. Non-Crystalline Solids, 29, 49 (1978).

実験・技術・調查報告・Report

\title{
セラミックスのダイヤモンド砥石による切断加エ
}

\author{
酒井清介・伊藤 勝 - 伊藤正治 \\ (名古屋工業技術試験所)
}

\begin{abstract}
セラミック材料の加工法を確立するため，その一部であるダイヤモンド砥石による切断加工法に おいて, ホットプレス窒化ケイ素の切断加工条件の選定とその問題点について検討した. 切断加工 にはメタルボンドとレジノイドボンドの両ダイヤモンド切断砥石を用い，加工中の負荷電流の測定 と同時にこれに伴う砥石表面の砥粒の摩耗の進行を走査型電子顕微鏡で観察した.

この結果, 次の結論を得た.

1） ホットプレス窒化ケイ素の切断加工に抒いては砥石外周面及び側面上のダイヤモンド砥粒の 摩耗が進行し，加工能率を著しく低下させるため目直し作業が不可欠である。

2) 砥石側面上の砥粒の摩耗によって負荷電流は大幅に増加するが，この砥石側面に $1 / 100$ 程度 のテーパーを付けることにより摩耗を防ぎ目直し間切断面積を大幅に上げることができる.

3）切断加工エネルギーは, 砥石切り込み深さが小さいほど少ない。（1981. 年 4 月 22 日受付)
\end{abstract}

\section{Cutting Process of Ceramics with Diamond Wheel}

\author{
Seisuke SAKAI, Masaru ITO and Shoji ITO \\ (Government Industrial Research Institute, Nagoya $)$
}

In order to establish the mechanical processing technique of ceramics, the cutting conditions and the other problems in the abrasive machining of hot-pressed silicon nitride with the cutting wheel are discussed. As the cutting tool, metal and resinoid bonded diamond wheels were used, and the load current was measured and the worn grains on the surface of the wheel were observed with SEM. The main results obtained are as follows:

1) The diamond grains on the external and the side surfaces of a wheel wore out remarkably in the cutting process of hot-pressed $\mathrm{Si}_{3} \mathrm{~N}_{4}$. Then the cutting load current increased on a large scale as the wear of grains. Therefore, the cutting efficiency lowered, and the dressing was indispensable in the cutting process with a diamond wheel.

2) The wear, however, was prevented by giving the taper of the order of $1 / 100$ on the side surface, and the redress life of the cutting wheel increased with this taper of both sides.

3) The cutting energy per unit area decreased as decreasing of depth of cut.

[Received April 22, 1981]

Key-words : Cutting process, Silicon nitride, Diamond wheel, Tapered cutting wheel, Grinding force

1. 緒言

工業材料としてのセラミックスは, 一般的に, 耐熱 性, 耐食性; 耐摩耗性等の点ですぐれた性能を示し, 特
に最近の咥化ケイ素ではその強度の向上も著しく ${ }^{11,2)}$, これらの特長を生かした構造材料への利用に対する期待 が大きい.一方，これらの材料の新たな分野での利用を 